RASĀYAN J. Chem.

Vol. 14 | No. 2 |705-711| April - June | 2021 ISSN: 0974-1496 | e-ISSN: 0976-0083 | CODEN: RJCABP http://www.rasayanjournal.com http://www.rasayanjournal.co.in

\title{
In-vitro ANTIFUNGAL EFFECT OF THE CAYENNE LEAF EXTRACT MODIFIED WITH LIQUID SMOKE FROM COCOA POD HUSK TO CONTROL F. OXYSPORUM ON CHILI (CAPSICUM ANNUUM L.)
}

\section{Muhammad Faisal ${ }^{1,2,3}$, Asri Gani ${ }^{1,4, \varpi}$, AR Nurul Hidayati ${ }^{1}$, Putri Mardhatillah $^{1}$ and H. Husni ${ }^{5}$}

${ }^{1}$ Chemical Engineering Department, Faculty of Engineering, Universitas Syiah Kuala Darussalam, Banda Aceh, 23111, Indonesia

${ }^{2}$ Center for Sustainable Agricultural and Rural Development, Universitas Syiah Kuala, Banda Aceh, 23111, Indonesia

${ }^{3}$ Halal Research Center, Universitas Syiah Kuala, Banda Aceh, 23111, Indonesia

${ }^{4}$ Research Center for Environmental and Natural Resources, Universitas Syiah Kuala, Banda Aceh, 23111, Indonesia

${ }^{5}$ Department of Plant Protection, Universitas Syiah Kuala, Banda Aceh, 23111, Indonesia

${ }^{\square}$ Corresponding Author: asri.gani@che.unsyiah.ac.id

\begin{abstract}
This study aims to evaluate the in vitro ability of biopesticides from a mixture of liquid smoke and cayenne pepper leaf extract to control the fusarium wilting on the chili pepper. Liquid smoke was prepared through the pyrolysis of cocoa pod husk at $380(\mathrm{~T} 1), 420(\mathrm{~T} 2)$, and $460^{\circ} \mathrm{C}$ (T3). The cayenne leaf extract containing flavonoid compounds was obtained by maceration process using $n$-hexane solvent. Biopesticides were prepared by mixing $2 \%$ liquid smoke (v/v) and cayenne leaf extract powder at the concentrations of $0.3,0.6$ and $0.9 \%(\mathrm{w} / \mathrm{v})$. The test results showed that the cocoa pod husk pyrolyzed at $420^{\circ} \mathrm{C}$ produced liquid smoke with the highest phenol and acetic acid content of $0.343 \%$ and $0.619 \%$ respectively. The study showed that liquid smoke (at various pyrolysis temperatures) and the cayenne leaf extract concentrations influenced the inhibition of Fusarium oxysporum on the chili pepper. The biopesticide inhibition test in this study showed that the highest inhibition of $81.1 \%$ was achieved in T2 liquid smoke and $0.9 \%$ cayenne leaf extract (w/v).
\end{abstract}

Keywords: Liquid Smoke, Cayenne Leaf Extract, Flavonoid, Fusarium Oxysporum, Inhibition.

RASĀYAN J. Chem., Vol. 14, No.2, 2021

\section{INTRODUCTION}

Indonesia is one of the top producers of cocoa beans. The Ministry of Agriculture of the Republic of Indonesia reported that cocoa production in 2019 amounted to 596,477 tons harvested from a total area of $1,683,868$ hectares. ${ }^{1}$ With such a volume, the cocoa production leaves a huge amount of agricultural waste in the form of cocoa pod husk, which is potential to be made liquid smoke as it consists of lignin (51.02\%), cellulose (17.27\%), hemicellulose $(18.90 \%)$ and other compounds. ${ }^{2}$ Other materials from agricultural by-products that have the potential to be liquid smoke include durian shell, ${ }^{3}$ oil palm empty fruit bunches (OPEFB), ${ }^{4}$ and palm kernel. ${ }^{5}$

Liquid smoke has a function as a biopesticide because it contains phenol, ketone and acetic acid components ${ }^{6}$ with phenol component itself functions as a bactericide due to its ability to increase the permeability of cell membranes, inactivating essential enzymes and destroying the functional genes of bacteria. Liquid smoke is effective in inhibiting the fungus Phytopthora palmivora. ${ }^{7}$ Another material from plants containing phenol compounds is cayenne leaf extract, as phenol is one of the secondary metabolites commonly found in plants. ${ }^{8}$ In addition to phenol compounds, cayenne leaf extract also

Rasayan J. Chem., 14(2), 705-711(2021)

http://dx.doi.org/10.31788/ RJC.2021.1426239

This work is licensed under a CC BY 4.0 license. 
RASĀYAN J. Chem.

Vol. 14 | No. 2 |705-711| April - June | 2021

contains long-chain carboxylic acid compounds and their derivatives that function as antimicrobials and antioxidants. Cayenne leaf extract is effective in preventing pathogen growth by forming an inhibition zone $>13 \mathrm{~mm}$ against Staphylococcus aureus. ${ }^{9}$

The agricultural industry in tropical countries including Indonesia is faced with many challenges. Some economically important food crops, for example, chili pepper, are susceptible to various types of plant diseases. One of the diseases that has caused losses and crop failure of nearly $50 \%$ in chili pepper production is fusarium wilt caused by Fusarium oxysporum ( F. oxysporum) fungus. ${ }^{10} \mathrm{~F}$. oxysporum is one of the pathogenic fungi that can cause health effects on plants, animals, and humans. ${ }^{11}$ The pathogenic fungus is soil-transmitted and usually destroys the roots in various horticultural crops such as tomatoes, ${ }^{12}$ causing plants to wither and then rot. ${ }^{13}$ In controlling this plant disease, farmers usually rely on synthetic chemicals ${ }^{14}$, with trifluoromethylpyrazole acyl urea ${ }^{15}$ being the most-frequently-used synthetic pesticide. ${ }^{14}$ However, the excessive use of synthetic chemicals can cause harmful effects on humans and the environment and negatively impacts biodiversity. Also, the use of synthetic pesticides causes various chronic diseases in humans. ${ }^{16}$

Today the use of natural pesticides has also been widely carried out, including the use of pyraclostrobin to control the pathogenic $F$. oxysporum. However, this method is not effective because it can interfere with the growth of the roots of the adjacent young plants. ${ }^{17}$ One other alternative that can be used to inhibit the growth of this pathogenic fungus is liquid smoke from the cocoa pods husk. The phenolic compounds in cocoa pod husk can cause protein coagulation to the microbial cells, thus causing microbial inhibition. ${ }^{18}$ According to a study by Lecomte et al. ${ }^{19}$, to control the pathogenic $F$. oxsyporum fungus, antagonistic microorganisms or extracts from plants can also be used.

This paper reports a preliminary study on the combination of liquid smoke from cocoa pod husk (LS$\mathrm{CPH})$ and cayenne leaf extract as an alternative biopesticide for controlling in vitro the fusarium wilt in pepper plants.

\section{Preparation of Liquid Smoke}

\section{EXPERIMENTAL}

Three $\mathrm{kg}$ of raw materials of cocoa pod husk was put into the pyrolysis reactor. It was pyrolyzed at the temperatures of $380(\mathrm{~T} 1), 420(\mathrm{~T} 2)$, and $460^{\circ} \mathrm{C}(\mathrm{T} 3)$ and the resulting smoke was condensed to produce liquid smoke. The preparation procedure was reproduced verbatim from the previous research methodology. ${ }^{20}$ The resulting liquid smoke was tested for phenol and acetic acid content using UV-Vis Spectrophotometry (Agilent Cary $60 \mathrm{UV}-\mathrm{Vis}$ ) and High-Performance Liquid Chromatography (HPLC) (Hitachi L-4200H).

\section{Extraction and Evaporation of Cayenne Leaf}

One kg of cayenne leaf was dried (desired moisture content: less than 5\%) and mashed. The dried powder of cayenne leaf was macerated using $\mathrm{n}$-hexane solvent $(1: 3 \mathrm{w} / \mathrm{v})$ for 24 hours to remove the sample fat, then filtered using filter paper. The fat-free powder was dried and macerated in $95 \%$ ethanol $(1: 3 \mathrm{w} / \mathrm{v})$ for 3 days, then filtered and evaporated at $80^{\circ} \mathrm{C}$ using a rotary evaporator (Eyela N-1100SWD). ${ }^{21}$

\section{F. oxysporum Preparation and Inhibition Test}

The equipment used was first sterilized using an autoclave at $121^{\circ} \mathrm{C}$ for 15 minutes. The media was prepared as follows: PDA powder (potato dextrose agar) was weighed, put into an Erlenmeyer, then dissolved with distilled water and stirred until it was homogeneous. The agar media was then sterilized using an autoclave. After sterilization, the media was cooled to $\pm 45-50^{\circ} \mathrm{C}$. A $1 \mathrm{~mL}$ mixture of liquid smoke and cayenne leaf extract was put into a petri dish using a micropipette, and then $9 \mathrm{~mL}$ of PDA gelatin was added. The agar media was then left to harden. F. oxysporum fungus was obtained from the isolation at the Laboratory of Plant Diseases. The fungus was inoculated into agar media that had been pierced with a $9 \mathrm{~mm}$ cork borer. The media was incubated at room temperature and observations of the diameter of the fungus were carried out once every 24 hours for 7 days.

The chili pepper (Capsicum annum L.) media was prepared as follows. Red chili pepper was sterilized and a $4 \mathrm{~mm}$ hole on the chili surface was drilled, into which $F$. oxysporum fungus was inoculated. Then the entire surface of the red chili was sprayed with a mixture of liquid smoke and cayenne leaf extract. 
RASĀYAN J. Chem.

Vol. 14 | No. 2 |705-711| April - June | 2021

Each of the fungus diameters on the chili was observed and measured every 24 hours for 3 days. For comparison, a controlled media was provided, to which no mixture of liquid smoke and cayenne leaf extract was added. The inhibition of the fungus growth was calculated as follows. ${ }^{22}$

$$
\begin{aligned}
& P=\frac{(a-b)}{a} \times 100 \% \\
& P \quad \text { : Inhibition } \\
& \mathrm{a} \quad \text { : Diameter of fungi colony (control) } \\
& \mathrm{b}
\end{aligned}
$$

\section{Analysis Results of Liquid Smoke Content}

\section{RESULTS AND DISCUSSION}

The test results of liquid smoke on HPLC and UV-Vis Spectrophotometry for the percentage of its phenol and acetic acid content at various pyrolysis temperatures are presented in Table-1.

Tabel-1: Phenol and Acetic Acid Content in Liquid Smoke at Various Pyrolysis Temperatures

\begin{tabular}{c|c|c}
\hline Liquid Smoke & Phenol (\%) & Acetic Acid (\%) \\
\hline T1 & 0.307 & 0.202 \\
\hline T2 & 0.343 & 0.619 \\
\hline T3 & 0.334 & 0.150
\end{tabular}

From Table-1, it can be seen that T2 liquid smoke has the highest content of phenol and acetic acid, which is $0.343 \%$ and $0.619 \%$ respectively. The phenol content found in liquid smoke is influenced by the lignin content in it. The higher the lignin content is, the higher the phenolic content will be. ${ }^{23}$ Liquid smoke has two main compounds with a bactericidal/bacteriostatic effect, namely, phenol and acetic acid in the form of a combination of compounds that work effectively to influence microbial growth. ${ }^{24}$ Detail composition of liquid smoke from cocoa pod husk has been discussed by Desvita et al. ${ }^{25}$ Based on this, liquid smoke can act as a natural pesticide to control various pest organisms in various crops. Several previous studies have also reported the content of phenols and acetic acid in liquid smoke with various concentrations. It was reported that cashew nut husk contained $36.6 \%$ phenol and $18.8 \%$ total acid. ${ }^{26}$ Liquid smoke from corn cobs had a phenol content of $1.22 \%$ and a total acid of $9.60 \% .{ }^{27}$ Liquid smoke from coconut shells had phenol content of $2.71 \%$ and acid $0.07 \%$, while liquid smoke from palm shells contained phenol compounds of $3.06 \%$ and acid compounds of $5.13 \% .{ }^{28}$

\section{F. oxysporum Inhibition by LS-CPH}

\section{Test Result of PDA Media}

The inhibition test of LS-CPH against $F$. oxysporum fungus on PDA media was carried out by inoculating pure fungus by diffusion method on PDA media. The amount of LS-CPH inhibition in PDA media treated with various types of liquid smoke (T1-T3) and concentration of cayenne leaf extract can be seen in Figs.1 and 2.

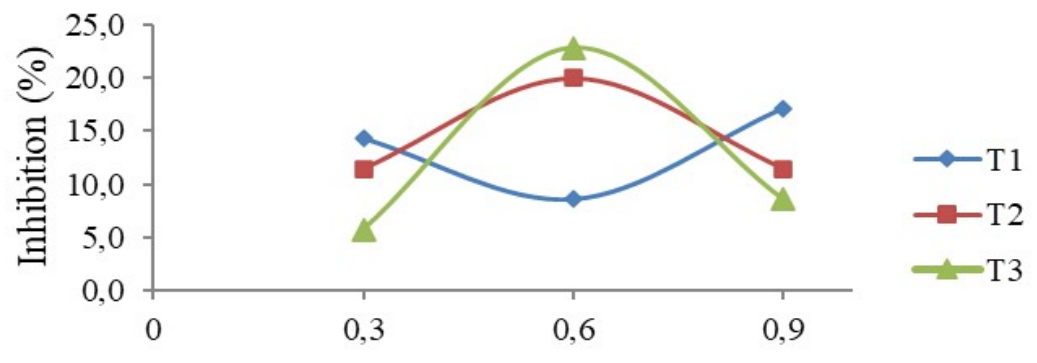

Cayenne leaf extract (\%)

Fig.-1: LS-CPH Inhibition to the Growth of F. oxysporum Fungus on PDA Media for Various Liquid Smoke (T1T3) with an Incubation Period of 24 hours. 
RASĀYAN J. Chem.

Vol. 14 | No. 2 |705-711| April - June | 2021

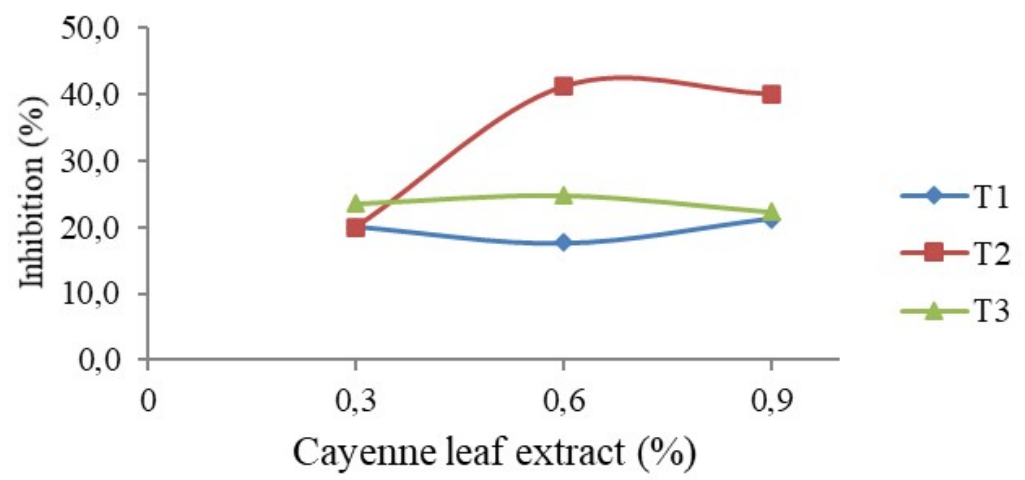

Fig.-2: LS-CPH Inhibition to the Growth of F. oxysporum Fungus on PDA Media for Various Liquid Smoke (T1T3) with an Incubation Period of 72 hours

Figures-1 and 2 show LS-CPH inhibition to the growth of $F$. oxysporum fungus on PDA media with an incubation period of 24 hours and 72 hours. LS-CPH inhibition against $F$. oxysporum fungus on T2 liquid smoke and cayenne leaf extract at $0.9 \%$ concentration produced the highest inhibitory antifungal activity, which was $40.1 \%$ ( 72 hours of incubation period). The results of the inhibition analysis indicated the influence of the mixture concentration of liquid smoke and cayenne leaf extract on PDA media on the growth of $F$. oxysporum fungus. The inhibition results were in line with Table-1, where T2 liquid smoke has high phenol and acetic acid content. A higher concentration of liquid smoke will have a better inhibitory effect on fungus growth. The antimicrobial effect of liquid smoke is due to its phenol content. The higher the phenol content is, the higher the antimicrobial activity will be. The antimicrobial mechanism of the phenol compound in liquid smoke takes place by damaging the cell wall and increasing the permeability of the cell membrane. ${ }^{29}$ The cayenne leaf extract can function as an antimicrobial because the extract in the form of ethanol, ethyl acetate, and methanol compounds can inhibit bacterial activity by interfering with cell membrane synthesis. ${ }^{21}$ Cayenne leaf extract contains phenols, which is $26.15 \pm 0.76$ ( $\mathrm{mg} / \mathrm{g}$ of dry extract weight) and flavonoids $12.84 \pm 0.22\left(\mathrm{mg} / \mathrm{g}\right.$ of dry extract weight). ${ }^{9,30}$

The application of liquid smoke from cocoa pod husk pyrolyzed at $500^{\circ} \mathrm{C}$ to inhibit the growth of $F$. oxysporum fungus was carried out by Pallawagau et al. ${ }^{18}$ The study found that the fungal inhibition in the application of $8 \%$ liquid smoke was $83.30 \%$, while at $9 \%$ concentration of liquid smoke, $F$. oxysporum fungus did not grow anymore. Also, another studies ${ }^{31}$ found that cocoa pod husk had the potential to inhibit $F$. oxysporum in tomato plants at the liquid smoke extract concentrations of $8 \%(\mathrm{v} / \mathrm{v})$, with an inhibition result of around $23.8 \%$.

\section{Test Results on Chili Media}

Fungal inhibition test on chili pepper was carried out by inoculating $F$. oxysporum fungus on the surface of the chili that had been pierced. The fungus was allowed to grow for a day, and then LS-CPH was applied to the entire surface of the chili.

Table-2: The Infection Diameter on Chili infected by F. oxysporum Fungus and the Inhibition Percentage of LS$\mathrm{CPH}$

\begin{tabular}{c|c|c|c|c}
\hline Liquid & Cayenne Leaf & \multicolumn{3}{|c}{ Infection Diameter (mm)/Inhibition (\%) } \\
\cline { 2 - 5 } Smoke & Extract (\%) & 24 hours & 48 hours & 72 hours \\
\hline \multirow{4}{*}{ T1 } & 0.3 & $0 / 0$ & $13.6 / 30.6$ & $18.6 / 17.7$ \\
\cline { 2 - 5 } & 0.6 & $0 / 0$ & $11 / 43.9$ & $16.1 / 28.7$ \\
\cline { 2 - 5 } & 0.9 & $0 / 0$ & $10.8 / 45.2$ & $14.8 / 34.8$ \\
\hline \multirow{3}{*}{ T2 } & 0.3 & $0 / 0$ & $6.1 / 68.8$ & $7.8 / 65.7$ \\
\cline { 2 - 5 } & 0.6 & $0 / 0$ & $4.8 / 75.8$ & $7.5 / 66.9$ \\
\cline { 2 - 5 } & 0.9 & $0 / 0$ & $2.9 / 85.4$ & $14.4 / 8.8$ \\
\hline \multirow{3}{*}{ T3 } & 0.3 & $0 / 0$ & $12.4 / 36.9$ & $10.8 / 52.5$ \\
\cline { 2 - 5 } & 0.6 & $0 / 0$ & $8.8 / 55.4$ & $10.1 / 55.2$ \\
\cline { 2 - 5 } & 0.9 & $0 / 0$ & $8.1 / 58.6$ & \\
\hline
\end{tabular}


RASĀYAN J. Chem.

Vol. 14 | No. 2 |705-711| April - June | 2021

Table-2 shows the infection diameter on chili infected by $F$. oxysporum fungus and the inhibition percentage of LS-CPH. Fungus diameter increased from 24 hours to 72 hours. Media with T1 liquid smoke showed a larger diameter of infection than that with T2 and T3 liquid smoke. In the first 24 hours of incubation, chili media did not show any infection, while at 48 hours of the incubation period, the media showed $F$. oxysporum fungal infection, marked by the infection diameter on the chili media. The largest inhibition was obtained in media with $\mathrm{T} 2$ liquid smoke combined with $0.9 \%$ cayenne leaf extract concentration, that is, $85.4 \%$. Meanwhile, the smallest inhibition was in T1 liquid smoke combined with $0.3 \%$ cayenne leaf extract, which was $30.6 \%$.

At 72 hours of incubation, chili media had an increase in infection by $F$. oxysporum. This was indicated by the increasing diameter of infection of the media infected by the fungus. The largest inhibition was obtained in T2 liquid smoke combined with $0.9 \%$ leaf extract concentration, that is, $81.8 \%$. The smallest inhibition was achieved in media with $\mathrm{T} 1$ liquid smoke combined with $0.3 \%$ extract concentration, which was $17.7 \%$. High concentrations of phenol and acetic acid in T2 liquid smoke could increase the inhibitory effects of the infection diameter by $F$. oxysporum fungal infections. Furthermore, the increase in the concentration of cayenne leaf extract affected the effectiveness of the diameter inhibition as well. Cayenne leaves contain antibacterial compounds, namely, capsaicin and dihydrocapsaicin. Capsaicin has an antibacterial mechanism by interfering with cell membrane synthesis, whereas dihydrocapsaicin is selectively active against bacterial cell walls. ${ }^{21}$ A study by Rachmawaty et al. ${ }^{31}$ proved the potential of liquid smoke from cocoa pod husk to inhibit $F$. oxysporum fungal infection in tomato plants, with the highest inhibition obtained at $2 \%$ liquid smoke (v/v), that is, $54 \%$. This shows that the inhibition obtained from the current study is higher than that of the previous study.

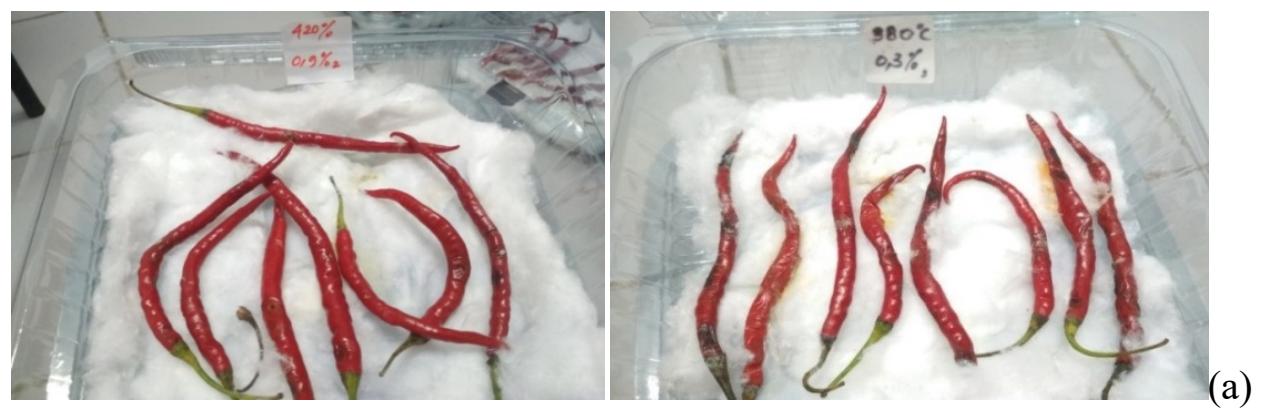

(b)

Fig.-3: The Preliminary Test of LS-CP as Biopesticide for F. oxysporum (a. Liquid Smoke T3 and 0.9\% Cayenne Leaf Extract; b. Liquid Smoke T1 and 0.3\% Cayenne Leaf Extract) (after 72 hours Incubation)

Figure-3 shows the differences in fungal infections on chili. Observation on the morphology of the fruit identified the symptoms of fusarium wilt characterized by the presence of brownish spots on the chili surface and it will become soft and rot. Symptoms of $F$. oxysporum fungal infection on plants are characterized by abnormal growth in leaves, where the leaves' green color fades away. Symptoms of wilting generally start from the leaves in the lower part of the plants then develop upward as the base of the stem begin to rot. ${ }^{31}$

In comparison, a study by Ceylan et al. ${ }^{32}$ found that the use of liquid smoke combined with thymol could inhibit bacterial growth by up to $60 \%$. Fusarium wilt disease in tomato plants could also be overcome by one of the biological controls, namely the bacterium Bacillus amyloliquefaciens, but the inhibition percentage of $F$. oxysporum fungal growth is $48.3 \%{ }^{33}$

\section{CONCLUSION}

LS-CPH has the potential as a biopesticide to control fusarium wilting in chili plants caused by $F$. oxysporum fungus. The smallest diameter of infection by $F$. oxysporum in chili pepper was obtained in $\mathrm{T} 2$ liquid smoke combined with $0.9 \%$ concentration of cayenne leaf extract. Under these conditions, the highest $F$. oxysporum fungal inhibition of $81.1 \%$ was achieved. The growth inhibition of $F$. oxysporum fungus was influenced by antimicrobial substances found in liquid smoke and cayenne leaf extract. The LS-CPH biopesticide is expected to replace the synthetic pesticides that have been used so far. 
RASĀYAN J. Chem.

Vol. 14 | No. 2 |705-711| April - June | 2021

\section{ACKNOWLEDGEMENT}

This work was funded by Universitas Syiah Kuala. The authors wish to thank the University for its Support.

\section{REFERENCES}

1. Ministry of Agriculture of Indonesia, Estate Crops Sub Sector, Jakarta, Indonesia (2020)

2. M.M. Wijaya, M.Wiharto and M. Anwar, Jurnal Kimia dan Pendidikan Kimia), 2(3), 191(2018), DOI:10.20961/jkpk.v2i3.11974

3. M. Faisal, A. Gani and F. Mulana, F1000 Research, 8(240) (2019), DOI:10.12688/f1000research.18095.6

4. M. Faisal, A. Gani, F. Mulana, H. Desvita and S. Kamaruzzaman, Rasayan Journal Chemistry, 13(1), 514 (2020), DOI:10.31788/RJC.2020.1315507

5. M. Faisal, A. Gani, Husni and H. Daimon, International Journal of GEOMATE, 13(37), 116 (2017), DOI: $10.21660 / / 2017.37 .2734$

6. Mashuni, M. Jahiding, I. Kurniasih and Zulkaidah, In AIP Conference Proceedings, 1823(1), 020008 (2017), DOI: 10.1063/1.4978081

7. M. Faisal, T. Chamzurni and H. Daimon, Internasional Journal of GEOMATE, 14(43), 36 (2018), DOI: 10.21660/2018.43.3531

8. R. R. Rodiah, I. N. Kundera and G. B. N. Shamdaz, Jurnal Ilmiah Penidikan Biologi, 5(1), 10 (2017)

9. N. Gurnani, M. Gupta, D. Mehta and B. K. Mehta, Journal of Taibah University for Science, 10(4), 462 (2016), DOI:10.1016/j.jtusci.2015.06.011

10. N. W. Sutarini, I. Sumiartha, N. Suniti, I. Sudiarta, G. N. A. S. Wirya and M. Utama, E-Jurnal Agroekotekonologi Tropika, 4(2), 135(2015)

11. T. R. Gordon, Annual Review of Phytopathology, 55, 23(2017), DOI:10.1146/annurev-phyto080615-095919

12. C. Srinivas, D. N. Devi, K. N. Murthy, C. D. Mohan, T. R. Lakshmeesha, B. Singh, N. K. Kalagatur, S.R. Niranjana, A. Hasheem, A.A. Alqarawi, B. Tabassum, E.A. Abdullah, C.Nayaka and R.K. Srivastava, Saudi journal of Biological Sciences, 26, 1315(2019), DOI:10.1016/j.sjbs.2019.06.002

13. E. T. Bodah, Agricultural Research and Technology: Open Access Journal, 5(3), 555661(2017), DOI:10.19080/ARTOAJ.2017.04.555661

14. G. M.W. Lengai, J. W. Muthomi and E. R. Mbega, Scientific African, 7 (e00239), 2468, (2019), DOI: 10.1016/j.sciaf.2019.e00239

15. H. Wang, Z.Zhai, Y. Shi, C.Tan, J. Weng, L. Han, B. Li and X. Liu,. Journal of Molecular Structure, 1171, 631(2018), DOI:10.1016/j.molstruc.2018.06.050

16. C. A. Damalas, In J. Selamat, S. Z. Iqbal(eds), Food Safety, Springer, 43(2016), DOI:10.1007/9783-319-39253-0_3

17. J. Luo, D. Zhang, T. Jing, G. Liu, H. Cao, B. Li, Y. Hou and F.Liu, Chemical Engineering Journal, 394, 124854(2020), DOI:10.1016/j.cej.2020.124854

18. M. Pallawagau, N. A., Yanti, M. Jahiding, L. O. Kadidae, W. A. Asis and F. H. Hamid, ALCHEMY Jurnal Penelitian Kimia, 15(1), 165(2019), DOI:10.20961/alchemy.15.1.24678.165-176

19. C.Lecomte, C. Alabouvette, V.Edel-Hermann, F. Robert and C. Steinberg, Biological Control, 101, 17 (2016), DOI:10.1016/j.biocontrol.2016.06.004

20. M. Faisal, A. Gani, Husni and H. Daimon, Journal of Engineering and Applied Sciences, 11(12), 2583 (2016), DOI:10.36478/jeasci.2016.2583.2587

21. R. Fauziyya, L.H.Nurani and N. Sulistyani, Traditional Medicine Journal, 22(3), 166(2017)

22. T. Kuswinanti, M. Junaid, Baharuddin and Melina, In IOP Conference Series: Earth and Environmental Science, 343(1), 012257(2019), DOI:10.1088/1755-1315/343/1/012257

23. R. A. Leviyani, R. A. Kurniasih and F. Swastawati, In IOP Conference Series: Earth and Environmental Science, 246(1), 012084 (2019), DOI:10.1088/1755-1315/246/1/012084 
RASĀYAN J. Chem.

Vol. 14 | No. 2 |705-711| April - June | 2021

24. I. K. Budaraga, Tukiran and Syamsuwirman, In IOP Conference Series: Earth and Environmental Science, 347(1), 012036 (2019), DOI:10.1088/1755-1315/347/1/012036

25. H. Desvita, M.Faisal, Mahidin and Suhendrayatna, International Journal of GEOMATE, 20(80), 17 (2021), DOI: 10.21660/2021.80.6154

26. L. Ifa, S. Yani, Z. Sabara, N. Nurjannah and A. Rusnaenah, In IOP Conference Series: Earth and Environmental Science, 175(1), 012033 (2018), DOI:10.1088/1755-1315/175/1/012033

27. T. Handayani, D.Xyzquolyna, Y. Pranoto and A. Suratman, In IOP Conference Series: Earth and Environmental Science, 292(1), 012003(2019), DOI:10.1088/1755-1315/292/1/012003

28. E.Sari, U. Khatab, Burmawi, E. D., Rahman, F. Afriza, A. Maulidita and V.Desti, In IOP Conference Series: Materials Science and Engineering, 543(1), 012075(2019), DOI:10.1088/1757899X/543/1/012075

29. S. I. Kailaku, M.Syakir, I. Mulyawanti and A. N. A. Syah, In IOP Conference Series: Materials Science and Engineering, 206(1), 012050 (2017), DOI:10.1088/1757-899X/206/1/012050

30. P. L. A. Nascimento, T.C. E. S. Nascimento, N. S. M. Ramos, G. R. Silva, J. E. G. Gomes, R. E. A. Falcão, K. A. Moreira ,A.L. F. Porto and T.M. S. Silva, Molecules, 19, 5434(2014), DOI:10.3390/molecules19045434

31. Rachmawaty, A.Mu'nisa, S. F. Hiola, A. Ali and Hasri, Journal of Physics: Conference Series, 1244(1), 012036 (2019), DOI:10.1088/1742-6596/1244/1/01203

32. Z. Ceylan, G. F. U. Sengor and M.T. Yilmaz, Journal of Food Engineering, 229, 43(2018), DOI:10.1016/j.jfoodeng.2017.11.038

33. K. Elanchezhiyan, U. Keerthana, K. Nagendran, S. R. Prabhukarthikeyan, K. Prabakar, T. Raguchander, G. Karthikeyan, Physiological and Molecular Plant Pathology, 103, 92 (2018), DOI:10.1016/j.pmpp.2018.05.008

[RJC-6239/2020] 